\title{
About the presence of the wood mouse Apodemus sylvaticus (Linnaeus, 1758) (Mammalia Rodentia Muridae) in a rocky habitat in the central Apennines (Italy)
}

\author{
Armando Nappi i*, Maurizio Fusari ${ }^{2}$, David Fiacchini ${ }^{3}$, Riccardo Castiglia ${ }^{4}$, Giovanni Amori ${ }^{5}$ \& Flavia Annesi ${ }^{6}$
}

\begin{abstract}
${ }^{1}$ Museo civico di Storia naturale, via Cortivacci 2, 23017 Morbegno, Sondrio, Italy; e-mail: armando.nappi@alice.it ${ }^{2}$ via Cardarelli 23,62100 Macerata, Italy; e-mail: maurizio.fusari@libero.it

${ }^{3}$ via Frontillo 29,62035 Valfornace, Macerata, Italy; e-mail: david.fiacchini@email.it

${ }^{4}$ Dipartimento di Biologia e Biotecnologie Charles Darwin, Università di Roma "La Sapienza", via Borelli 50, 00161 Roma, Italy; e-mail: riccardo.castiglia@uniroma1.it

${ }^{5}$ C.N.R., Istituto di Ricerca sugli Ecosistemi Terrestri, Viale dell'Università 32, 00185 Roma, Italy; e-mail: g.amori@cnr.it ${ }^{6}$ Dipartimento di Biologia e Biotecnologie Charles Darwin, Università di Roma "La Sapienza", via Borelli 50, 00161 Roma, Italy; e-mail: flavia.annesi@uniromal.it

${ }^{*}$ Corresponding author
\end{abstract}

ABSTRACT

In this paper, some data about the presence of Apodemus sylvaticus (Linnaeus, 1758) (Mammalia Rodentia Muridae) in rocky environments of the National Park of the Sibillini Mountains are provided. Considering the available data on the distribution of $A$. sylvaticus in Italy, this appears to be an unusual finding, which can be explained considering the strong reduction that the preferred environment by this species, the wooded areas, has suffered in the past by man and possible competitions with other forest rodents.

KEY WORDS

Apodemus; ecology; Sibillini; Marche; Italy.

Received 26.11.2018; accepted 19.12.2018; printed 30.12.2018; published online 07.01.2019

\section{INTRODUCTION}

The wood mouse, Apodemus sylvaticus (Linnaeus, 1758) (Mammalia Rodentia Muridae), is a rodent distributed throughout Europe (with the exception of Finland and northern parts of Scandinavia, the Baltic and Russia) and parts of North Africa (Schlitter et al., 2016).

In Italy, it is present throughout the territory, including Sicily and Sardinia (Capizzi \& Filippucci, 2008), and on some small islands such as Pantelleria, Favignana, Marettimo, Ischia, Vivara, Montecristo, Giglio, Elba, Asinara, Caprera, La Maddalena and Spargi (Angelici et al., 2009).

In peninsular Italy, the distinction on the mor- phological basis with the congeneric $A$. flavicollis (Melchior, 1834), is often difficult even if, the two species, are separated from the genetic point of view (Witte, 1964; Niethammer, 1969; Recco et al., 1978; Nascetti et al., 1980; Gemmeke, 1980; Contoli et al., 1984).

With regard to environmental presences, in the atlas of European mammals (Montgomery, 1999), it is reported as a species present in woodlands of all kinds, moors, riparian habitats, agricultural land, forestry plantations, suburban but also urban areas if parkland or railway embankments are available; particularly, the western populations are associated with several habitats, the eastern ones are common in woodland edge habitats and the most extreme 
populations live in the steppeland. Finally, it is one of the most common small mammals found in the more arid Mediterranean habitats.

In his work on Italian rodents, Santini (1983) reports A. sylvaticus as a very adaptable species, which can be found in any biotope with herbaceous vegetation and some shrubs.

In the recent review on Erinaceomorpha, Soricomorpha, Lagomorpha and Rodentia of the "Fauna d'Italia" series (Capizzi \& Filippucci, 2008), it is reported as a predominantly forest species but able to live in other environments such as hedges, uncultivated and cultivated fields, parks and gardens.

In this paper, some data about the presence of A. sylvaticus in rocky environments of the National Park of the Sibillini Mountains are provided.

The National Park of the Sibillini Mountains, established in 1993, extends for little less than 70,000 hectares in the territory of two regions (Marche and Umbria, central Italy). The mountainous chain giving its name to the protected area is purely calcare-

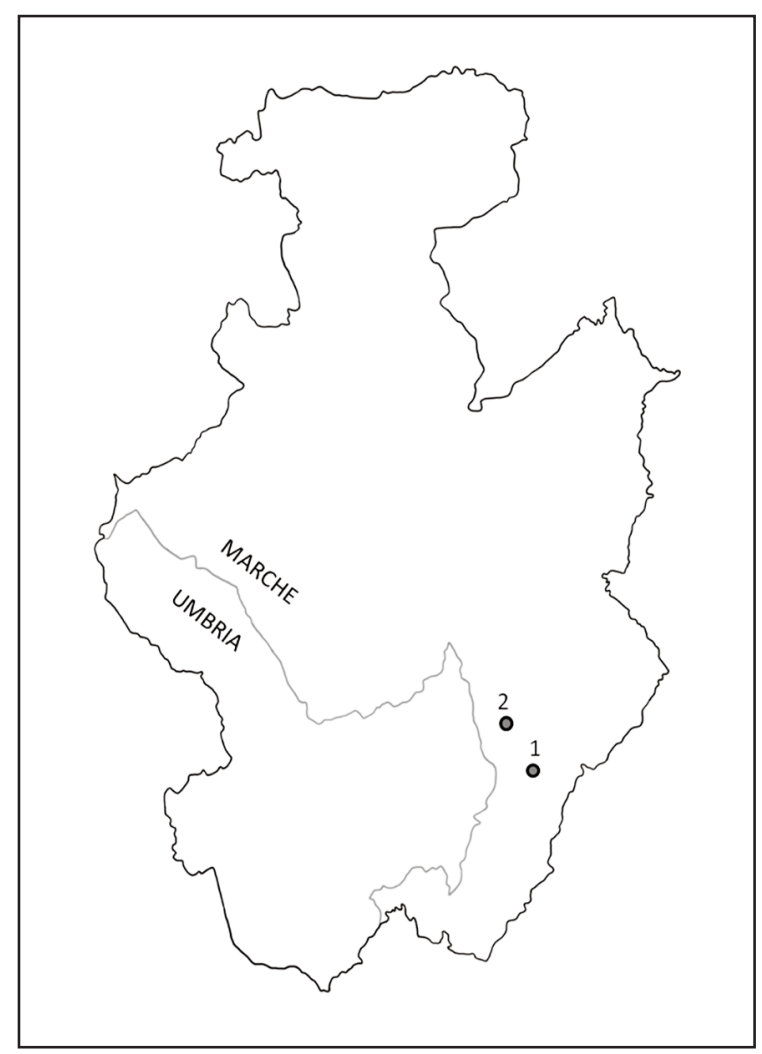

Figure 1. The perimeter of the National Park of the Sibillini Mountains and the localities considered in our research. 1: Rifugio Zilioli, 2: Pizzo del Diavolo eastern side. ous, spreading for about $30 \mathrm{~km}$ and it was deeply modeled by the action of glaciers during Quaternary, whose traces are still recognizable in the beautiful glacial cirques of the Mount Vettore $(2,476 \mathrm{~m})$, of the Mount Sibilla $(2,173 \mathrm{~m})$ and of the Mount Bove $(2,169 \mathrm{~m})$, where human presence has always been limited.

Descending from the main axis of the Apennine ridge, an eastern slope characterized by narrow valleys oriented northwards and a western slope in which it can find typical depressions of the high altitudes: the karst phenomena are particularly evident in the plains of Castelluccio di Norcia and in the numerous sink-holes, tracks and cavities to be found along the main valleys.

The hill areas, mostly marly-arenaceous, are more anthropized, as well as the valley floors: specialized farming and small industrial areas, arisen next to the most populated towns, characterize the legal borders of the Park.

From the main ridge, representing the watershed between the Tyrrhenian and the Adriatic sides, many inaccessible and wild valleys degrade, crossed by rivers and torrents such as Rio Sacro, Fiastrone, Ambro, Tenna, Aso, Fluvione on the Adriatic side, Nera and Ussita on the Tyrrhenian side. The northern and southern borders of the Park are individuated by Chienti and Tronto rivers respectively.

In the territory of the protected area lake basins are also present: the Lake Fiastrone, created in 1,955 for hydroelectric purposes, and the Lake Pilato, small cirque basin located at 1,941 $\mathrm{m}$ asl, the only natural lake in the Marche region.

From the botanical point of view the Park, registering more than 1,800 floral species, is characterized by extended secondary meadow pastures, by downy oak woods (hill plain), by mixed deciduous forest and residual beechwood strips, undergoing forestry practices (mountain plain) over $1,800 \mathrm{~m}$ a.s.l., even though reduced in comparison to the past, where primary grasslands develop (Pedrotti, 2002).

It is necessary to mention how during the centuries the human activities traditionally linked to animal farming have caused a relevant reduction of the forest environment, favouring secondary mountain grasslands. By the way, these grasslands have become important ecosystems, protected also at an EU level, because of their richness in rare or en- 


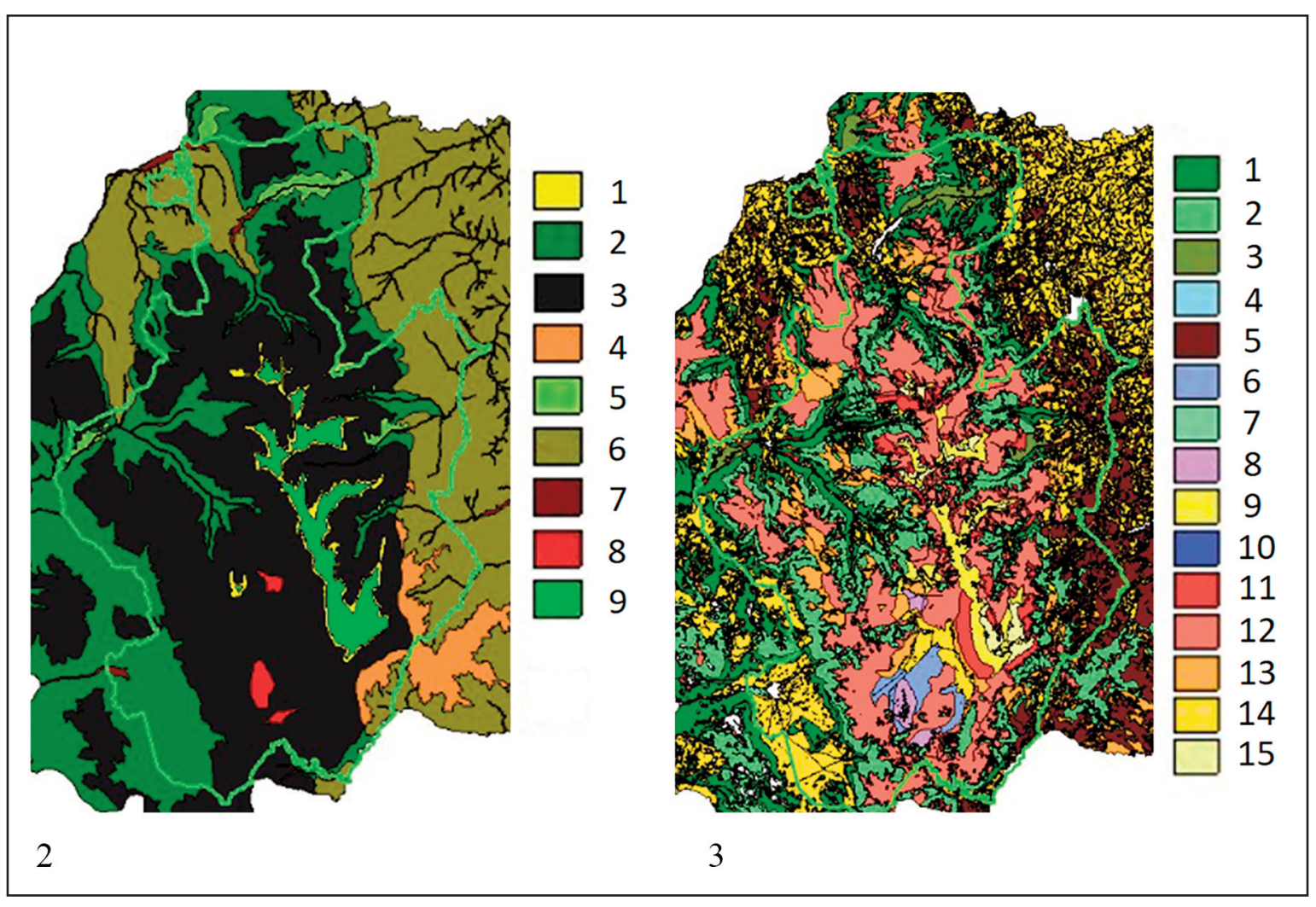

Figure 2. Potential vegetation of the National Park of the Sibillini Mountains and surrouding areas (from www.sibillini.net/il_parco/index.php). 1: subalpine shrubs (Prunetaliae); 2: European hop-hornbeam forests (Quercetalia pubescentis, Laburno-Ostryon); 3: beech forests on calcareous substrate (Fagetalia sylvaticae); 4: beech forests on marlyarenaceous substrate (Fagetalia sylvaticae); 5: evergreen oak forests (Quercetalia illicis); 6: downi oak and locally Turkey oak forests (Quercetalia pubescentis, Quercion pubescentis); 7: riparial forests (Salicetalia purpureae, Populetalia albae); 8: marshy meadows (Magnocarioetalia); 9: primary meadows (Seslerietalia apenninae).

Figure 3. Real vegetation of the National Park of the Sibillini Mountains and surrouding areas (from www.sibillini.net/il_parco/index.php). 1: European hop-hornbeam and manna ash forests; 2: beech forests; 3: evergreen oak forests; 4: riparial forests; 5: downi oak and locally Turkey oak forests; 6: mowing grassland; 7: hygrophile meadows; 8: met grass meadows; 9: primary meadows; 10: marshy meadows; 11: secondary open meadows; 12: secondary sluice meadows; 13: abandoned fields; cultivated fields.

demic floral species and as a fundamental habitat for several animal species.

Fauna is also relatively diversified; about 200 vertebrate species are esteemed, even though there is still little information about the real size and chorology of small mammals and bats' populations (Fermanelli, 2002; Fiacchini \& Rossetti, 2013). In 2008, the Apennine chamois (Rupicapra pyrenaica ornata Neumann, 1899) has been successfully introduced, in the wild, thanks to a Life project that involved four national parks (Rossetti et al., 2015; Bocci et al., 2016; Antonucci \& Di Domenico, 2015).

Due to the relevant biodiversity value and to the presence of several habitats of naturalistic interest, 18 Special Areas of Conservation (SACs) and 5 Special Protection Areas (SPA) were established, according to the Habitats Directive 92/43/CEE, to the Directive 79/409/CEE and to the Birds Directive 2009/147. These areas, fully or partly included in the Park, build the framework of the Natura 2000 network in the southern portion of the UmbrianMarchean Apennines and have an important part in the project "APE - Apennines Park of Europe".

The National Park of the Sibillini Mountains is a territory where biodiversity, history and culture has contributed in defining a unique and unrepeatable reality. 
The localities considered in the present paper (Fig. 1), in particular, are the following: Rifugio Zilioli (Arquata del Tronto, Ascoli Piceno province), mountain hut surrounded by stony ground and meadows, 2,242 m asl; Pizzo del Diavolo eastern side (Montemonaco, Ascoli Piceno province), stony ground, 1,892-1,979 $\mathrm{m}$ asl.

\section{MATERIAL AND METHODS}

During a research committed by National Park of the Sibillini Authority to confirm the presence of the snow vole Chionomys nivalis (Martins, 1842) (Rodentia Cricetidae) in the protect area (Nappi et al., 2017), some trapping sessions were carried out in 11 stations of the Park, by using sherman, longworth, trip trap, home made cage traps and hair tubes. The captures and the tissue sampling were performed under authorization of the National Park Authority.

Since the morphological similarity with A. flavicollis, to identify the specimens we sequenced a fragment of the mitochondrial gene for the $\mathrm{Cy}$ tochrome b (cytb) following the protocol in Nappi et al. (2017). Briefly, a tissue sample was collected from the ear flap with a biopsy punch and stored in $95 \%$ ethanol.

Genomic DNA was extracted by means of the universal extraction protocol of Aljanabi \& Martinez (1997) with proteinase K and DNA precipitation with isopropanol. We used standard PCR protocols to amplify two mitochondrial fragments of cytochrome b (cytb). The primers used for the amplifications were L15408-ATA GAC AAA TCC CAT TCC A and H15915-TCT CCA TTT CTG GTT TAC AAG AC.

Amplifications were performed by polymerase chain reaction (PCR) in a Biometra Thermocycler machine. Sequencing was carried out by an external service (MACROGEN). The resulting sequence was 1071 bp (GenBank accession number to be provided upon acceptance). We used the blastn suite (Altschul et al., 1990) to identified the specimens.

\section{RESULTS}

The blastn suite, run with the obtained sequenced (442-445 bp), clearly indicated that the specimens belonged to A. sylvaticus having a $99 \%$ of identity with other $A$. sylvaticus sequences present in GenBank.

Two A. sylvaticus were captured around the Rifugio Zilioli (03.VII.2014) and two in Pizzo del Diavolo eastern side (03.VII.2014 and 06.VII.2014).

\section{DISCUSSION}

Although A. sylvaticus is an adaptable species, it does not seem to be reported, in Italy, in rocky environments. In Lombardia, A. sylvaticus was recorded in a great variety of habitats, except the rocky areas (Canova, 2001); in Umbria, it is present in deciduous, evergreen sclerophylls and riparian habitats, in grasslands, cultivated field and urban areas (Gaggi \& Paci, 2014); in Roma province, it was found in very extensive woods, cultivated fields and urban areas (Capizzi, 2009).

As regards to the territory of the National Park of the Sibillini Mountains, from a research carried out in Val di Bove by the analysis of red fox Vulpes vulpes (Linnaeus, 1758) and mustelids scats, the presence of Apodemus sp. was detected in a border environment between coniferous forest and secondary grassland, between 1,500 and 1,700 m (Gaggi et al., 2013).

Considering the map of the potential vegetation of the Sibillini Mountains (Fig. 2), one can be deduced that in the past, the wooded areas, favorite environments of $A$. sylvaticus, were much more extensive. Although the majority of the environments present today, in the Park, is also suitable for A. sylvaticus (Fig. 3), the competition with rodents more related to woods, shrublands and grasslands, may have pushed some individuals to environments where the species, at least in Italy, is not reported.

\section{ACKNOWLEDGEMENTS}

We thank the National Park of the Sibillini Mountains (Visso, Macerata, Italy) for financing part of the research, for according the trapping authorization and the utilisation of the figures $2-3$, with particular thanks to Paolo Salvi and Alessandro Rossetti (Visso, Macerata, Italy) for their technical and logistic support. We thank also Angela and 
Roberta Gaggi (Città di Castello, Perugia, Italy), Andrea Maria Paci (Città di Castello, Perugia, Italy) for their kind cooperation.

\section{REFERENCES}

Aljanabi S.M. \& Martinez I., 1997. Universal and rapid salt-extraction of high quality genomic DNA for PCR-based techniques. Nucleic Acids Research, 25: 4692-4693.

Altschul S.F., Gish W., Miller W., Myers E.W. \& Lipman D.J., 1990. Basic local alignment search tool. Journal of Molecular Biology, 215: 403-410.

Angelici F.M., Laurenti A. \& Nappi A., 2009. A checklist of the mammals of small Italian islands. Hystrix, the Italian Journal of Mammalogy (n.s.), 20: 3-27.

Antonucci A. \& Di Domenico G. (Eds.), 2015. Chamois International Congress Proceedings. 17-19 June 2014, Lama dei Peligni, Majella National Park, Italy, $272 \mathrm{pp}$.

Bocci A., Menapace S., Alemanno S. \& Lovari S., 2016. Conservation introduction of the threatened Apennine chamois Rupicapra pyrenaica ornata: Post-release dispersal differs between wild-caught and captive founders. Oryx, 50: 128-133.

Canova L., 2001. Apodemus sylvaticus (Linnaeus, 1758) Topo selvatico. In: Prigioni C., Cantini M. \& Zilio A. (Eds.), Atlante dei Mammiferi della Lombardia. Regione Lombardia e Università degli Studi di Pavia, 197-199.

Capizzi D., 2009. Apodemus sylvaticus (Linnaeus, 1758) Topo selvatico. In: Amori G., Battisti C. \& De Felici S. (Eds.), I Mammiferi della Provincia di Roma. Dallo stato delle conoscenze alla gestione e conservazione delle specie. Provincia di Roma, Assessorato alle Politiche dell'Agricoltura. Stilografica, Roma, 176-177.

Capizzi D. \& Filippucci M.G., 2008. Apodemus sylvaticus (Linnaeus, 1758). Distribuzione geografica. In: Amori G., Contoli L. \& Nappi A. (Eds.), Mammalia II. Erinaceomorpha, Soricomorpha, Lagomorpha, Rodentia. Collana "Fauna d'Italia". Vol. XLIV. Edizioni Calderini del Il Sole 24 ORE Business Media Srl, Milano, 609-610.

Contoli L., Cristaldi M., Filippucci M.G., Tizi L. \& Vigna Taglianti A. (Eds.), 1984. Recenti acquisizioni sul genere in Italia. Atti del I Seminario dell'Associazione Teriologica Romana (As.Te.Ro.), Supplemento alle Ricerche di Biologia della Selvaggina, 9: $1-176 \mathrm{pp}$.

Fermanelli A. (Ed.), 2002. Piano per il Parco. Unpublished document, Ente Parco nazionale dei Monti Sibillini, Visso, 53 pp.
Fiacchini D. \& Rossetti A., 2013. Il Parco nazionale dei Monti Sibillini. In: Fiacchini D. (Ed.), Atlante degli Anfibi e dei Rettili del Parco nazionale dei Monti Sibillini. Ente Parco Nazionale dei Monti Sibillini, Collana "Quaderni scientifico-divulgativi", vol. 16. Editrice GESP, Città di Castello, 10-12.

Gaggi A. \& Paci A.M., 2014. Atlante degli Erinaceomorfi, dei Soricomorfi e dei piccoli Roditori dell'Umbria. Regione Umbria, Perugia, 211 pp.

Gaggi A., Paci A.M. \& Fiacchini D., 2013. First data on small mammals of Val di Bove (Sibillini National Park, Marche, Italy). In: Bertolino S., Capizzi D., Mori E., Colangelo P. \& Scaravelli D. (Eds.), Secondo convegno Italiano sui Piccoli Mammiferi, Libro dei riassunti, p. 37.

Gemmeke H., 1980. Proteinvariation und Taxonomie in der Gattung Apodemus (Mammalia, Rodentia). Zeitschrift für Säugetierkunde, 45: 358-365.

Montgomery W.I., 1999. Apodemus sylvaticus (Linnaeus, 1758). In: Mitchell-Jones A.J., Amori G., Bogdanowicz W., Kryštufek B., Reijnders P.J.H., Spitzenberger F., Stubbe M., Thissen J.B.M., Vohralík V. \& Zima J. (Eds.), The Atlas of European Mammals. T. \& A.D. Poyser, Natural History, London, pp. 274-275.

Nappi A., Paci A. M., Fusari M., Gaggi A., Fiacchini D., Romano C., Castiglia R., Annesi F., Amori G., Mosci P. \& Ricci G., 2017. The snow vole Chionomys nivalis (Martins, 1842) (Mammalia, Rodentia, Cricetidae) on the Sibillini Mountains (Central Italy). Rendiconti Lincei, 28: 589-594. DOI 10.1007/s 12210-017-0644-9

Nascetti G., Tizi L. \& Bullini L., 1980. Differenziazione biochimica e variabilità genetica in due popolazioni simpatriche di Apodemus sylvaticus (L. 1758) e Apodemus flavicollis (Melchior, 1834) (Rodentia, Muridae). Accademia Nazionale dei Lincei. Rendiconti della classe di Scienze Fisiche, Matematiche e Naturali, 67 (serie 8): 131-136.

Niethammer J., 1969. Zur Frage der Introgression bei den Waldmäusen Apodemus sylvaticus und A. flavicollis. Zeitschrift für zoologisches Systematik und Evolutionforschung, 7: 77-127.

Pedrotti F., 2002. Flora, vegetazione e paesaggio vegetale del Parco Nazionale dei Monti Sibillini. Ente Parco Nazionale dei Monti Sibillini, quaderni scientificodivulgativi, n. 3/2002. Aniballi Grafiche srl, Ancona, $48 \mathrm{pp}$.

Recco M., Federici R. \& Cristaldi M., 1978. Presenza simpatrica di Apodemus flavicollis e di Apodemus sylvaticus nelle zone di Tolfa e Manziana: considerazioni critiche. Bollettino del Museo Civico di Storia Naturale di Verona, 5: 313-353.

Rossetti A., Menapace S., Morandi F., Alemanno S., Bocci A., Salvi P., Mari F. \& Perco F., 2015. The apennine chamois reintroduction in the monti Sibillini National 
Park: population monitoring and status at six years from the reintroduction beginning. In: Antonucci A. \& Di Domenico G. (Eds.), Chamois International Congress Proceedings. 17-19 June 2014, Lama dei Peligni, Majella National Park, Italy, pp. 21-31.

Santini L., 1983. I Roditori italiani di interesse agrario e forestale. Collana del progetto finalizzato "Promozione della qualità dell'ambiente". Consiglio Nazionale delle Ricerche AQ/1/232, Padova, 168 pp. Schlitter D., van der Straeten E., Amori G., Hutterer R.,
Kryštufek B., Yigit N. \& Mitsain G., 2016. Apodemus sylvaticus (errata version published in 2017). The IUCN Red List of Threatened Species 2016: e.T1904A115059104. DOI: 10.2305/IUCN.UK. 2016-3.RLTS.T1904A22423831.en. Downloaded on 13 July 2018.

Witte G., 1964. Introgression bei Apodemus sylvaticus und A. flavicollis. Biometrische Untersuchungen an Apodemus-Populationen des Monte Gargano (Süditalien). Bonner zoologische Beiträge, 15: 159-177. 